\title{
UPAYA PENINGKATAN KEMAMPUAN PEMECAHAN MASALAH MATEMATIKA MELALUI PENERAPAN MODEL PEMBELAJARAN KEPALA BERNOMOR STRUKTUR
}

\author{
Helma Mustika ${ }^{1}$, Devi Mei Riska ${ }^{2}$ \\ ${ }^{1}$ Program Studi Pendidikan Matematika STKIP Insan Madani Airmolek \\ ${ }^{2}$ Mahasiswa Program Studi Pendidikan Matematika STKIP Insan Madani Airmolek \\ helmamustika@ymail.com¹, meiriskadevi@gmail.com²
}

\begin{abstract}
This study aims to improve students' mathematical problem-solving abilities by applying the learning model with head numbered structure. This type of research is the Class Action Research (CAR). Data collection techniques used were tests and observations. The instruments used were the problem-solving ability test, observation sheet and data analysis techniques using the problem-solving indicator values. Based on the results of the problemsolving ability test that on indicator 1 that fulfills the completeness of learning in the first cycle $63 \%$, and the second cycle 78\%. Indicator 2 in cycle I 59\%, and cycle $270 \%$. Indicator 3 in cycle I as 52\% and cycle II is 67\%. Indicator 4 in cycle I 48\%, and cycle II 63\%. So it can be concluded that the students' mathematical problem-solving abilities increase through the application of the learning model with head numbered structure.
\end{abstract}

Key words: Head Number Structure, Problem Solving

\begin{abstract}
Abstrak. Penelitian ini bertujuan untuk meningkatkan kemampuan pemecahan masalah matematika siswa dengan penerapan model pembelajaran kepala bernomor struktur. Jenis penelitian ini adalah Penelitian Tindakan Kelas (PTK). Teknik pengumpulan data yang digunakan adalah Tes dan Observasi. Instrumen yang digunakan adalah tes kemampuan pemecahan masalah, lembar observasi dan teknik analisis data menggunakan nilai indikator pemecahan masalah. Berdasarkan hasil tes kemampuan pemecahan masalah bahwa pada indikator 1yang memenuhi ketuntasan belajar pada siklus I 63\%, dan siklus II 78\%. Indikator 2 pada siklus I 59\%, dan siklus II 70\%. Indikator 3 pada siklus I 52\%, dan siklus II 67\%. Indikator 4 pada siklus I 48\%, dan siklus II 63\%. Jadi dapat disimpulkan bahwa kemampuan pemecahan masalah matematika siswa meningkat melalui penerapan model pembelajaran kepala bernomor struktur.
\end{abstract}

Kata kunci: Kepala Bernomor Struktur, Pemecahan Masalah

\section{PENDAHULUAN}

Proses pembelajaran matematika mampu melatih berpikir seseorang secara logis, kritis, dan kreatif selain itu matematika merupakan ilmu dasar dari perkembangan sains dan sangat berguna dalam kehidupan. Pada setiap lapisan masyarakat seperti apapun profesi dan pekerjaannya tetap dituntut untuk mengetahui matematika kemudian berupaya untuk belajar dan memahaminya. Matematika mempelajari tentang pola keteraturan, tentang struktur yang terorganisasi. Oleh karena itu, matematika dapat masuk dalam seluruh segi kehidupan manusia dari yang paling sederhana sampai yang paling kompleks. Peranan matematika tidak hanya tertuju pada peningkatan kemampuan untuk berhitung kuantitatif tetapi juga untuk penataan cara berfikir dan khususnya dalam pembentukan kemampuan analisis, sintesis, evaluasi dan pemecahan masalah.

Kusumawati \& Mawardi (2016) menjelaskan bahwa hakikat pembelajaran matematika difokuskan pada bagaimana cara menyelesaikan masalah. Dunia matematika mempunyai masalah yang cara penyelesaiannya dapat dilakukan hanya melalui satu solusi dan ada pula masalah yang solusinya bisa ditempuh melalui berbagai cara. Melihat karakter matematika yang mempunyai berbagai macam cara penyelesaian suatu masalah, maka diperlukan kemampuan memahami masalah, menyelesaikan masalah, dan menemukan 
solusinya; jadi pada hakikatnya pembelajaran matematika lebih ditekankan pada kemampuan berpikir.

Tujuan dari penelitian ini adalah untuk meningkatkan kemampuan pemecahan masalah matematika melalui penerapan model pembelajaran kepala bernomor struktur di kelas VI SD Negeri 004 Sukajadi Kecamatan Lirik Kabupaten Indragiri Hulu. Penelitian ini mengacu pada rumusan masalah yaitu Apakah Ada Peningkatan Kemampuan Pemecahan Masalah Matematika Siswa melalui Penerapan Model Pembelajaran Kepala bernomor struktur di Kelas VI ${ }^{\mathrm{B}}$ SD Negeri 004 Sukajadi. Berdasarkan rumusan masalah tersebut maka hipotesis tindakan dalam penelitian ini adalah ada peningkatan Kemampuan Pemecahan Masalah Matematika Siswa di Kelas VI ${ }^{\mathrm{B}}$ SD Negeri 004 Sukajadi melalui Penerapan Model Pembelajaran Kepala Bernomor Struktur. Salah satu komponen yang turut serta memberikan pengaruh terhadap kesuksesan suatu proses pembelajaran adalah penerapan model pembelajaran yang relevan dengan bidang kajian yang dibelajarkan. Suprijono (2011:58) menegaskan pembelajaran yang dapat memacu siswa berinteraksi dengan baik dengan siswa lainnya, dapat dilakukan guru dengan cara menerapkan model pembelajaran kooperatif.

Pembelajaran dengan model kepala bernomor struktur merupakan model pembelajaran dimana para siswa dibentuk menjadi beberapa kelompok kecil dan diberikan nomor, masing-masing nomor siswa tersebut diberikan tugas yang tidak sama dan nantinya setiap siswa yang nomornya sama dapat bergabung dengan kelompok lain untuk melakukan kerjasama. Model pembelajaran kepala bernomor struktur ini merupakan penyempurnaan dari model pembelajaran numbered head together. Dengan kepala bernomor terstruktur siswa belajar melaksanakan tanggung jawab pribadinya dalam saling keterkaitan dengan rekan-rekan kelompoknya (Lie, 2010). Kepala bernomor terstruktur memudahkan dalam pembagian tugas. Sehingga dapat meningkatkan pemahaman konsep matematis siswa dibandingkan dengan pembelajaran konvensional.

Perbedaannya adalah terdapat pada penugasan dan pada masuk keluarnya anggota kelompok. Model pembelajaran kepala bernomor struktur diawali dengan Siswa dibagi dalam kelompok, setiap siswa dalam setiap kelompok mendapat nomor selanjutnya Penugasan diberikan kepada setiap siswa berdasarkan nomorkan terhadap tugas yang berangkai, misalnya: siswa nomor satu bertugas mencatat soal. Siswa nomor dua mengerjakan soal dan siswa nomor tiga melaporkan hasil pekerjaan dan seterusnya. Jika perlu, guru bisa menyuruh kerja sama antar kelompok. Siswa diminta keluar dari kelompoknya dan bergabung bersama beberapa siswa bernomor sama dari kelompok lain. Dalam kesempatan ini siswa dengan tugas yang sama bisa saling membantu atau mencocokkan hasil kerja sama mereka kemudian Laporkan hasil dan tanggapan dari kelompok yang lain. Langkah terakhir dari model kepala bernomor struktur ini adalah kesimpulan, guru dan siswa menarik kesimpulan dari proses pembelajaran. Menurut Hamruni (2012), efektivitas suatu proses pembelajaran ditandai dengan adanya suasana belajar yang kondusif diantaranya terjalin hubungan dan kerja sama antar siswa dengan baik, sehingga aktivitas belajar siswa menjadi menarik dan menyenangkan. Aktivitas belajar yang efektif dapat membantu siswa untuk meningkatkan kemampuan yang diharapkan sesuai dengan tujuan instruksional yang ingin dicapai (Hamdani, 2011).

Jadi, dapat di simpulkan bahwa model pembelajaran kepala bernomor struktur adalah suatu model pembelajaran kelompok dengan nomor dikepala siswa, setiap siswa mempunyai tugas masing-masing lalu bekerja sama antar kelompok, siswa diminta keluar dan bergabung dengan siswa yang bernomor sama dari kelompok lain, dan melaporkan hasil kerja mereka.

Salah satu hal yang dianggap perlu untuk ditingkatkan dalam proses pembelajaran siswa adalah kemampuan pemecahan masalah matematika. Kemampuan pemecahan 
Upaya peningkatan kemampuan pemecahan masalah matematika melalui...

masalah matematika sebagai salah satu aspek kemampuan berpikir tingkat tinggi, didefinisikan oleh Cooney (Nasir, 2008), sebagai proses menerima masalah dan berusaha menyelesaikan masalah itu. Sedangkan Polya (Hudojo, 1979) mendefinisikan pemecahan masalah sebagai usaha mencari jalan keluar dari suatu kesulitan, mencapai suatu tujuan yang tidak dengan segera dicapai. Selanjutnya Polya mengatakan bahwa pemecahan masalah merupakan suatu tingkat aktivitas intelektual untuk mencari penyelesaian masalah yang dihadapi dengan menggunakan bekal pengetahuan yang sudah dimiliki.

Dalam penelitian ini kemampuan pemecahan masalah yang akan diukur melalui kemampuan siswa dalam menyelesaikan suatu masalah dengan menggunakan langkahlangkah pemecahan masalah menurut Polya yaitu: (1) memahami masalah, (2) menyusun rencana pemecahan masalah, (3) melaksanakan rencana penyelesaikan masalah, dan (4) melakukan pengecekan kembali, dengan alasan strategi tersebut umum digunakan.

\section{METODE}

Jenis penelitian ini adalah Penelitian Tindakan Kelas (PTK), metode yang berasal dari kata dasar penelitian tindakan. Menurut Arikunto (2013) penelitian tindakan kelas merupakan suatu pencermatan terhadap kegiatan belajar berupa sebuah tindakan. Adapun siklus penelitian tindakan kelas didalam buku Suharsimi Arikunto adalah sebagai berikut.

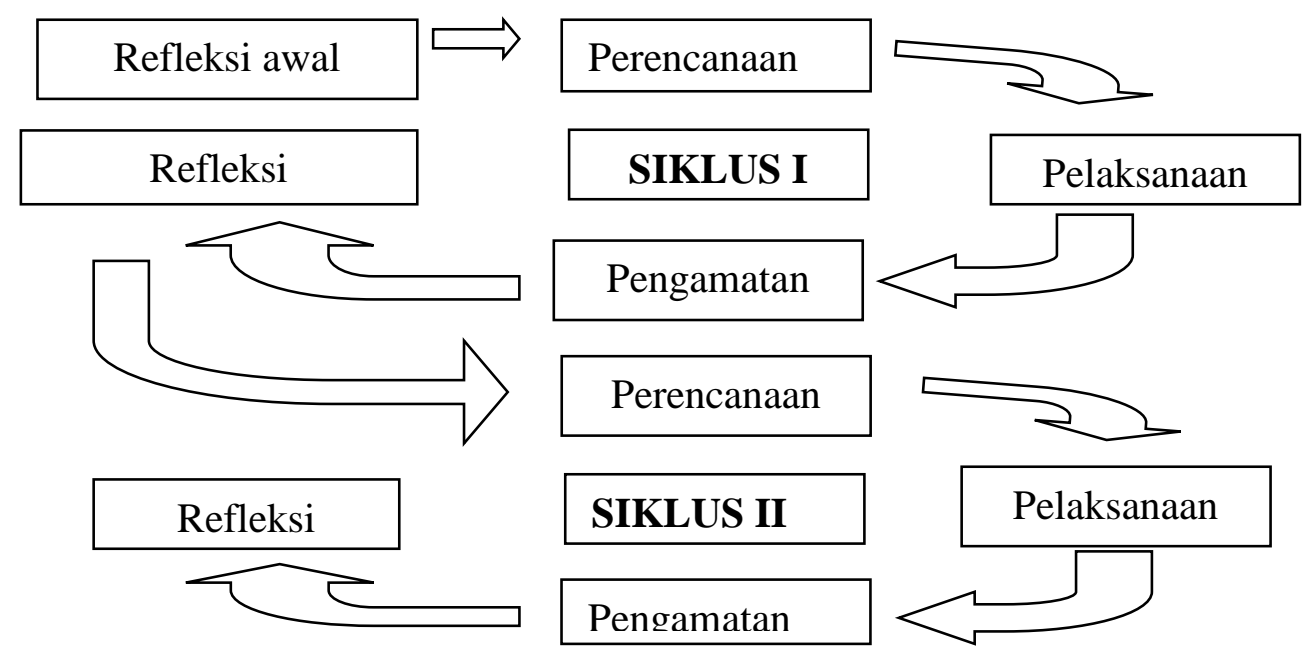

Gambar 1. Alur Penelitian Tindakan Kelas (Arikunto, 2013)

Teknik pengumpulan data yang digunakan adalah Tes dan Observasi. Instrumen yang digunakan adalah tes kemampuan pemecahan masalah, lembar observasi dan teknik analisis data menggunakan nilai indikator pemecahan masalah.

\section{HASIL DAN PEMBAHASAN}

Hasil penelitian ini terdiri atas hasil pra tindakan dan hasil tindakan. Dalam pra tindakan peneliti memberikan materi yang akan dipelajari pada siswa dan menjelaskan materi dengan metode ceramah dan tidak menggunakan model pembelajaran kepala bernomor struktur. Kemudian memberikan tes awal kemampuan pemecahan masalah dari materi yang dipelajari. Kegiatan ini dilakukan untuk mengetahui kemampuan pemecahan masalah siswa sebelum dilakukannya tindakan sebagai acuan untuk dilaksanakan kegiatan pada siklus I. Hasil tes awal disajikan pada tabel berikut. 
Tabel 1. Hasil Tes Awal Kemampuan Pemecahan Masalah

\begin{tabular}{|c|c|c|}
\hline $\begin{array}{c}\text { Indikator Kemampuan Pemecahan Masalah } \\
\text { Matematika }\end{array}$ & Tes Awal & Persentase \\
\hline $\begin{array}{l}\text { Kemampuan siswa mengidentifikasi data } \\
\text { diketahui dan ditanyakan, kecukupan data untuk } \\
\text { pemecahan }\end{array}$ & 16 siswa & $59 \%$ \\
\hline $\begin{array}{l}\text { Kemampuan siswa mengidentifikasi strategi yang } \\
\text { dapat ditempuh }\end{array}$ & 14 siswa & $52 \%$ \\
\hline $\begin{array}{l}\text { Kemampuan siswa menyelesaikan model } \\
\text { matematika disertai alasan }\end{array}$ & 12 & $44 \%$ \\
\hline $\begin{array}{l}\text { Kemampuan siswa memeriksa kebenaran } \\
\text { solusi yang diperoleh }\end{array}$ & 10 siswa & $37 \%$ \\
\hline
\end{tabular}

Setelah pelaksanaan kegiatan dilakukan dan peneliti telah menemukan adanya kendala dan keberhasilan dalam kegiatan pada Siklus I yaitu materi operasi hitung bilangan bulat yang mengarah pada kemampuan pemecahan masalah matematika siswa pada Siklus I dapat dilihat pada tabel dan diagram berikut.

Tabel 2. Hasil Tes Kemampuan Pemecahan Masalah Siklus I

\begin{tabular}{lcccc|c|}
\hline $\begin{array}{l}\text { Indikator Kemampuan Pemecahan } \\
\text { Masalah Matematika }\end{array}$ & $\begin{array}{c}\text { Tes } \\
\text { Awal }\end{array}$ & Persentase & Siklus I & Persentase \\
\hline $\begin{array}{l}\text { Kemampuan siswa mengidentifikasi } \\
\text { data diketahui dan ditanyakan, } \\
\text { kecukupan data untuk pemecahan }\end{array}$ & $\begin{array}{c}16 \\
\text { siswa }\end{array}$ & $59 \%$ & 17 siswa & $63 \%$ \\
\hline $\begin{array}{l}\text { Kemampuan siswa mengidentifikasi } \\
\text { strategi yang dapat ditempuh }\end{array}$ & $\begin{array}{c}14 \\
\text { siswa }\end{array}$ & $52 \%$ & 16 siswa & $59 \%$ \\
\hline $\begin{array}{l}\text { Kemampuan siswa menyelesaikan } \\
\text { model matematika disertai alasan }\end{array}$ & $\begin{array}{c}12 \\
\text { siswa }\end{array}$ & $44 \%$ & 14 siswa & $52 \%$ \\
\hline $\begin{array}{l}\text { Kemampuan siswa memeriksa } \\
\text { kebenaran solusi yang diperoleh }\end{array}$ & $\begin{array}{c}10 \\
\text { siswa }\end{array}$ & $37 \%$ & 13 siswa & $48 \%$ \\
\hline
\end{tabular}

Berdasarkan pelaksanaan tindakan kelas siklus I, siswa yang memiliki kemampuan mengidentifikasi data diketahui dan ditanyakan, kecukupan data untuk pemecahan sebanyak 17 siswa (63\%), siswa yang memiliki kemampuan mengidentifikasi strategi yang dapat ditempuh sebanyak 16 siswa (59\%), siswa yang memiliki kemampuan menyelesaikan model matematika disertai alasan sebanyak 14 siswa (52\%), dan siswa yang memiliki kemampuan melihat memeriksa kebenaran solusi yang diperoleh sebanyak 13 siswa (48\%). Dari hasil presentase terjadi peningkatan kemampuan pemecahan masalah matematika. 
Upaya peningkatan kemampuan pemecahan masalah matematika melalui...

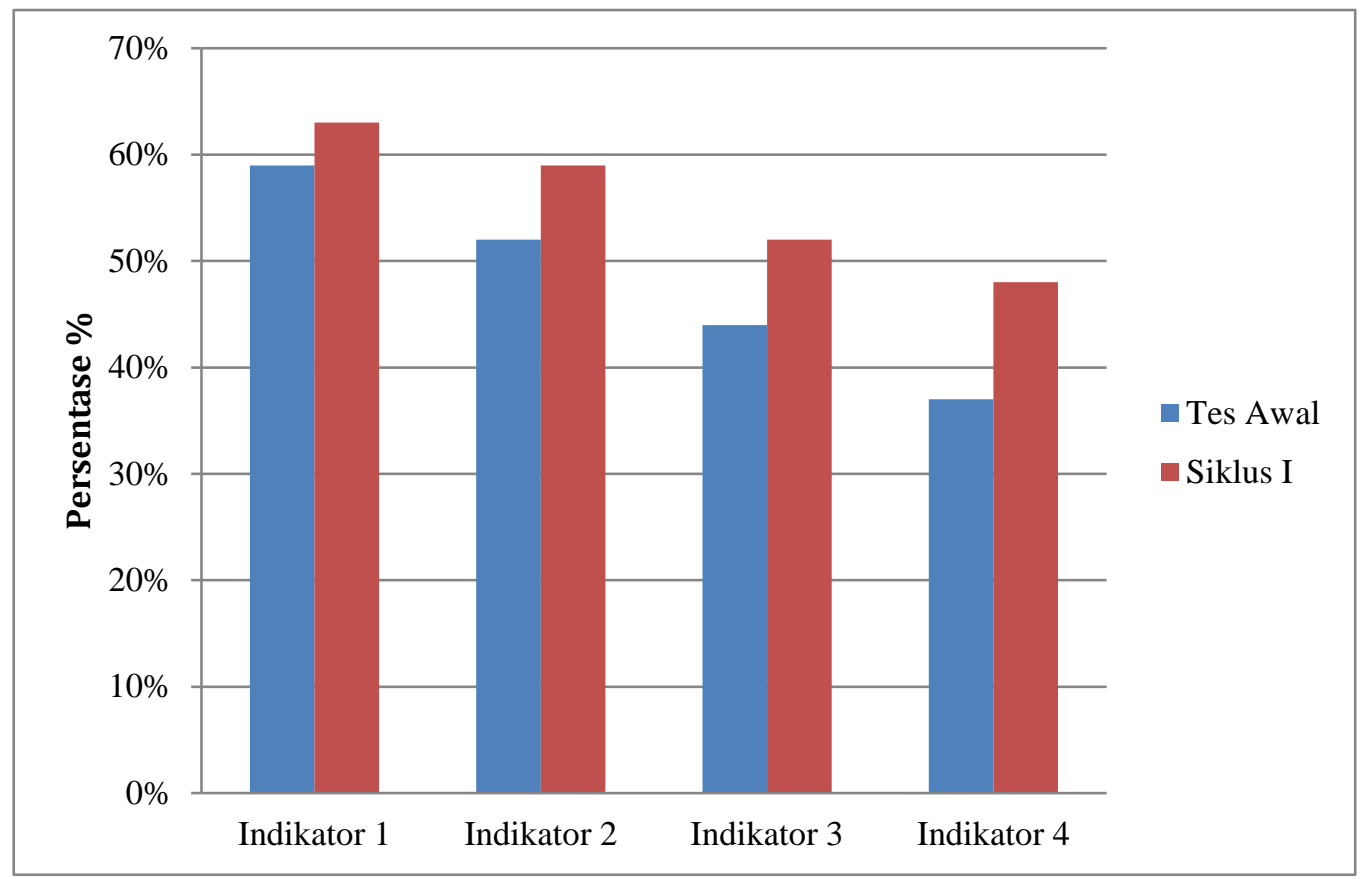

Gambar 2. Diagram Indikator Pemecahan Masalah Siswa Tes Siklus I

Setelah pelaksanaan tindakan dilakukan dan peneliti telah menemukan keberhasilan dalam kegiatan siklus II dalam lembar observasi kegiatan siswa, siswa diberi tes kemampuan pemecahan masalah matematika siswa. hasil tes kemampuan pemecahan masalah matematika siswa dapat dilihat pada tabel dan diagram berikut

Tabel 3. Hasil Tes Kemampuan Pemecahan Masalah Siklus II

\section{Kemampuan Pemecahan}

Masalah Matematika

Kemampuan siswa

mengidentifikasi data diketahui dan ditanyakan, kecukupan data untuk Siklus I Persentase

17 siswa

$63 \%$

21 siswa

$78 \%$

\begin{tabular}{llllll}
\hline $\begin{array}{l}\text { Kemampuan } \\
\text { mengidentifikasi strategi } \\
\text { dapat ditempuh }\end{array}$ & $\begin{array}{r}\text { siswa } \\
\text { yang }\end{array}$ & 16 siswa & $59 \%$ & 19 siswa & $70 \%$ \\
\hline $\begin{array}{l}\text { Kemampuan siswa } \\
\text { menyelesaikan model matematika } \\
\text { disertai alasan }\end{array}$ & 14 siswa & $52 \%$ & 18 siswa & $67 \%$ \\
\hline $\begin{array}{l}\text { Kemampuan siswa memeriksa } \\
\text { kebenaran solusi yang diperoleh }\end{array}$ & 13 siswa & $48 \%$ & 17 siswa & $63 \%$ \\
\hline
\end{tabular}

Pada tindakan siklus II, kemampuan pemecahan masalah matematika pada siswa sudah mengalami peningkatan sesuai dengan harapan peneliti dan guru matematika. Adapun data hasil tindakan siklus II yaitu siswa yang memiliki kemampuan mengidentifikasi data diketahui dan ditanyakan, kecukupan data untuk pemecahan sebanyak 21 siswa (78\%), siswa yang memiliki kemampuan mengidentifikasi strategi yang dapat ditempuh sebanyak 19 siswa (70\%), siswa yang memiliki kemampuan menyelesaikan model matematika disertai alasan sebanyak 18 siswa (67\%), dan siswa yang memiliki kemampuan melihat memeriksa kebenaran solusi yang diperoleh sebanyak 17 siswa (63\%). 


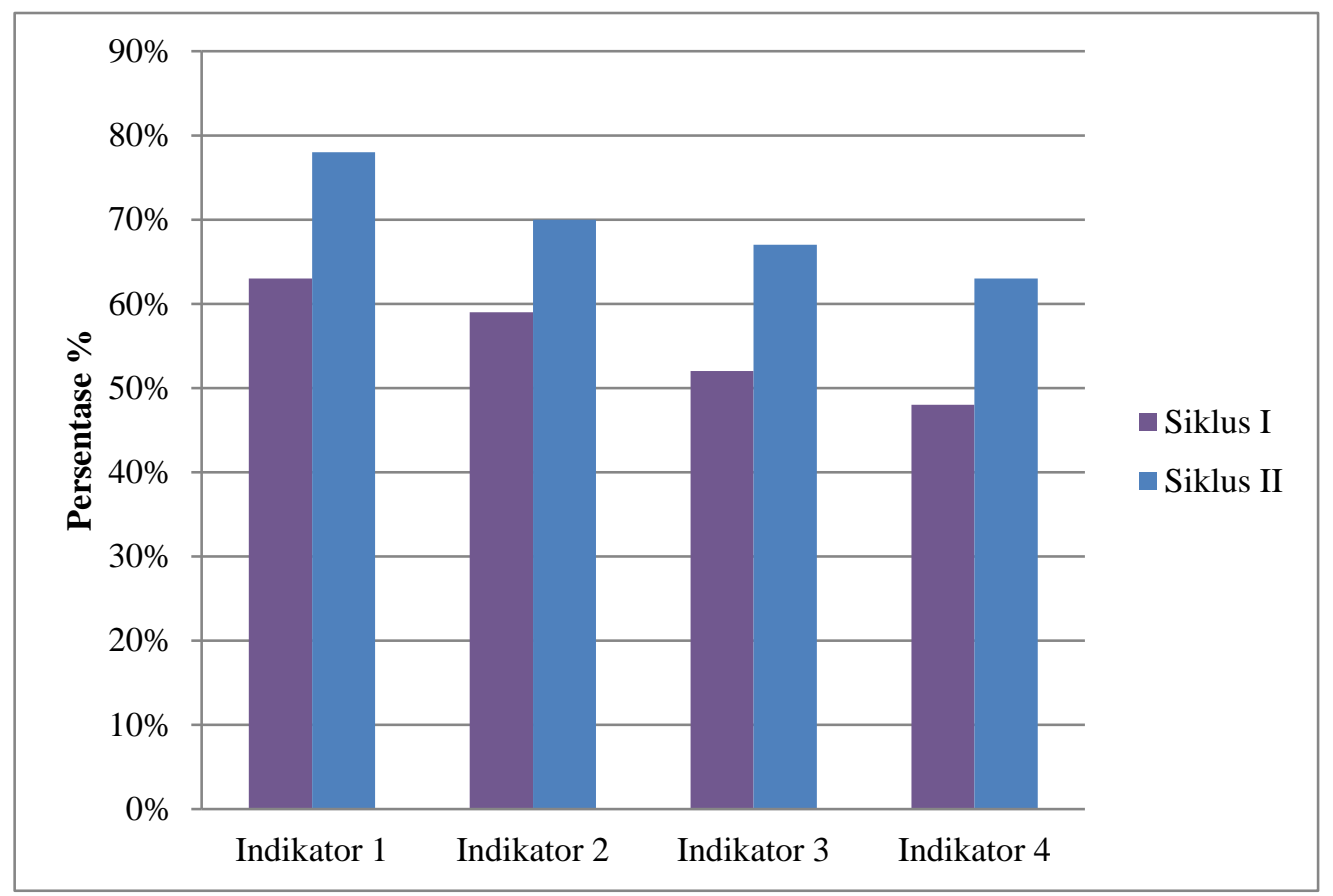

Gambar 2. Diagram Indikator Pemecahan Masalah Siswa Tes Siklus II

\section{KESIMPULAN}

Berdasarkan hasil penelitian tindakan kelas yang telah dilakukan di kelas $\mathrm{VI}^{\mathrm{B}} \mathrm{SD}$ Negeri 004 Sukajadi, dapat diambil kesimpulan bahwa dengan model pembelajaran kepala bernomor struktur dapat meningkatkan kemampuan pemecahan masalah matematika siswa. Hal tersebut dapat dilihat dari tercapainya indikator-indikator kemampuan pemecahan masalah matematika, yaitu: (1). Kemampuan siswa mengidentifikasi data diketahui dan ditanyakan, kecukupan data untuk pemecaham sebanyak 16 siswa (59\%), setelah dilakukan tindakan pada siklus I sebanyak 17 siswa (63\%), dan diakhir siklus II sebanyak 21 siswa (78\%). (2). Kemampuan siswa mengidentifikasi strategi yang ditempuh sebelum tindakan sebanyak 14 siswa (52\%), setelah dilakukan tindakan pada siklus I sebanyak 16 siswa (59\%), dan diakhir siklus II sebanyak 19 siswa (70\%). (3). Kemampuan siswa menyelesaikan model amtematika disertai alasan sebelum tindakan sebanyak 12 siswa (44\%), setelah dilakukan tindakan pada siklus I sebanyak 14 siswa (52\%), dan diakhir siklus II sebanyak 18 siswa (67\%). (4). Kemampuan siswa memeriska kebenaran solusi yang diperoleh sebelum tindakan sebanyak 10 siswa (37\%), setelah dilakukan tindakan pada siklus I sebanyak 13 siswa (48\%), dan diakhir siklus II sebanyak 17 siswa (63\%).

\section{UCAPAN TERIMA KASIH}

Penyelesaian penelitian ini telah banyak mendapatkan bimbingan serta dorongan dari berbagai pihak baik moral maupun material. Untuk itu penulis mengucapkan terima kasih kepada Keluarga Besar Sekolah Tinggi Keguruan dan Ilmu Pendidikan (STKIP) Insan Madani Aimolek dan Kelurga Besar SD Negeri 004 Sukajadi Kecamatan Lirik.

\section{DAFTAR PUSTAKA}

Arikunto, S. 2013. Prosedur Penelitian. Jakarta: PT Rineka Cipta. . 2013. Penelitian Tindakan Kelas. Jakarta: Bumi Aksara.

Hamdani. 2011. Strategi Belajar Mengajar. Bandung: CV Pustaka Setia Hamruni. 2012. Strategi Pembelajaran. Yogyakarta: Insan Madani 
Upaya peningkatan kemampuan pemecahan masalah matematika melalui...

Hudojo, H. (1979). Pengembangan Kurikulum Matematika dan Pelaksanaannya di Depan Kelas. Surabaya: Usaha Nasional.

Kusumawati, H., \& Mawardi, M. 2016. Perbedaan Penerapan Model Pembelajaran Kooperatif Tipe NHT dan STAD Ditinjau dari Hasil Belajar Siswa. Scholaria: Jurnal Pendidikan Dan Kebudayaan, 6(3), 251-263. https://doi.org/https://doi.org/10.24246/j.scholaria.2016.v6.i3.p251-263.

Lie, A. 2010. Cooperative Learning. Jakarta: PT Gramedia Widiasarana Indonesia

Nasir, S. 2008. Meningkatkan Kemampuan Koneksi dan Pemecahan Masalah Matematika Siswa SMA yang Berkemampuan Rendah melalui Pendekatan Kontekstual. Tesis UPI: Tidak diterbitkan

Suprijono, A. 2011. Cooperative Learning Teori dan Aplikasi Paikem. Yogyakarta: Pustaka Pelajar. 